\title{
Effect of flooding on the physicochemical quality of Mehmeh stream, Lokoja, Nigeria
}

\author{
Edmund OKORIE*, Abdulrashid SALAWU SIYAKA and Faith ITODO OJOTULE \\ Department of Science Laboratory Technology, School of Technology, Federal Polytechnic Idah, \\ P.M.B. 1037 Idah, Kogi State, Nigeria. \\ *Corresponding author; E-mail: e.okorieslt@yahoo.com
}

\begin{abstract}
The effect of flooding on the physicochemical quality of Mehmeh River in Lokoja Nigeria was studied. The metallic content of the river was carried out using flame atomic absorption spectrometry. Results of this study indicated an increase in the concentrations of the parameters studied. A comparative study on the concentrations before and during the flood indicated objectionable increase in the values of the parameters due to the upsurge in the particulate matter as the water traverses its course. Parameters such as temperature, turbidity, conductivity, total solids were higher in concentration during the flooding than before the flood. The $\mathrm{pH}$ and alkalinity were less during the flood than prior to the flood plausibly due to the large volume of total soluble solids. The $\mathrm{pH}$ range during the flood was 6.3-6.9, while 6.89-7.8 was recorded before the flood. Heavy and alkaline metals were observed to increase tremendously during the flood than before the flood. Such increase occurred in the metals: $\mathrm{Cu}, \mathrm{Pb}, \mathrm{Fe}, \mathrm{Cr}, \mathrm{Ni}, \mathrm{Ca}, \mathrm{K}$ and $\mathrm{Na}$. However, $\mathrm{Cd}$ and $\mathrm{Zn}$ were not detected. It was also observed that anthropogenic activities contributed to these increase in metal concentration as wastewater from both industrial and domestic sources are discharged into the water body by inhabitants living around the area.

(c) 2014 International Formulae Group. All rights reserved.
\end{abstract}

Keywords: Flood, pollution, heavy metals, physicochemical, FAAS.

\section{INTRODUCTION}

The pollution of surface water is of great concern in the present world due to increase in the rate of urbanization and industrialization. Water pollution is an acute problem in all the major rivers in Nigeria (Adebowale et al., 2008). River Mehmeh is a tributary to river Niger in Lokoja confluence town in Nigeria. The river flows from Barrack Otokiti through Phase II to Dunamis Bridge and empties into the River Niger. Inhabitants along the water course dump refuse and other wastes into the river. Because of water shortages, it is also a source of water to some inhabitants for domestic purposes. The distance between the sampling points are approximately $3 \mathrm{Km}$ apart.

During the flooding that occurred between June to November 2012, there was a backflow of water from the river Niger to river Mehmeh due to the massive water that surged through as a result of the opening of the Kainji Dam in North Central Nigeria. With these development, major changes in quality occurred such as the suspended solids concentration, dissolved solids, and algal 
content. Chemical stratification due to biological activities and thermal effect also may have occurred. Physicochemical and biological transformations may be directly affected by these changes (Toufeek, 2005). The water quality characteristics is denoted by knowing the physical parameters like $\mathrm{pH}$, total solid, temperature, turbidity and conductivity while chemical parameters such as alkalinity, hardness and heavy metal presence are equally of concern in assessing water quality. About $80 \%$ of water from World Health Organization (W.H.O.) estimates are polluted in developing countries. The improper management of water systems may cause serious problems in availability and quality of water (Subba Rao and Subba Rao, 1995).

The aim of this work is to ascertain the level of changes in some physicochemical parameters of Mehemeh river from January 2012 (before the flood) to August 2012 (peak period of flood in river Niger).

\section{MATERIALS AND METHODS Sampling}

Samples of the Mehmeh River were collected from three locations at $2 \mathrm{Km}$ intervals. The first was at barrack Otokiti followed by Phase II and finally at downstream Dunamis bridge. Sampling was conducted between June 2012 and September 2012. The sampled waters were stored in polythene bottles and brought to the laboratory for the analysis of various physicochemical parameters.

\section{Materials}

The materials used for this research are Benchtop conductivity meter (Hanna instruments), $\mathrm{pH}$ meter (Hanna pH 211 Microprocessor), turbidimeter (Hanna instruments), thermometer (Brannan Nitrogen filled, England), hot plate, measuring cylinder, FAAS (Buck scientific model AVG 210, U.K.), analytical balance (Mettler Toledo PR
2002), refrigerator, centrifuge (IECCentraCL), flame photometer.

Reagents used are methyl orange, $\mathrm{NaOH}, \mathrm{HCl}$, distilled water. All reagents are analytical grade types.

\section{Procedure \\ Determination of $p H$}

The $\mathrm{pH}$ was determined using Hanna pH211 microprocessor $\mathrm{pH}$ meter. The meter was switched on and standardized by connecting the glass electrode to the buffer solution. The beaker containing buffer solution was then replaced with the ones containing raw water samples and the electrode was inserted into it. This was allowed to stabilize and the readings recorded (SMEWW, 2005).

\section{Determination of electrical conductivity}

The electrode was wetted thoroughly and then plugged into the conductivity meter before it was inserted into a $250 \mathrm{~mL}$ beaker containing distilled water. The conductivity meter was then switched on and zero error was corrected. The distilled water was replaced with raw water samples and the electrode was inserted in each case. The system was allowed to stabilize and the reading was recorded (SMEWW, 2005).

\section{Determination of temperature}

The temperature of each sample was taken at sampling point by the use of thermometer (Brannan nitrogen filled, England). This was done by inserting the thermometer into the stream.

\section{Determination of turbidity}

The curvette of the turbidimeter was first rinsed with the water sample and filled to the marked point with the sample. This was then inserted into the turbidimeter after which the reading was taken (SMEWW, 2000).

\section{Determination of total solids}

Empty beaker was initially weighed, 50 $\mathrm{mL}$ of the water sample was measured and poured into the weighed beaker and heated gently to dryness at about $70{ }^{\circ} \mathrm{C}$. This was 
then cooled and reweighed. The process was repeated until a constant mass was obtained and the value recorded (SMEWW, 2005).

\section{Determination of alkalinity}

About $10 \mathrm{~mL}$ of water sample was pipette into a conical flask. Three drops of methyl orange indicator was added and titrated with $0.1 \mathrm{M} \mathrm{NaOH}$ to give an orange colour (SMEWW, 2005).

\section{Determination of metals}

Potassium and sodium were determined

by standard procedure using flame photometer, while $\mathrm{Cd}, \mathrm{Zn}, \mathrm{Cu}, \mathrm{Pb}, \mathrm{Fe}, \mathrm{Cr}, \mathrm{Ni}$ and $\mathrm{Ca}$ were determined after digestion with $\mathrm{HCl}$ using a Buck scientific Model AVG 210 flame atomic absorption spectrophotometer (Burrell, 1975).

\section{RESULTS}

The results of the effect of flooding on the physicochemical quality of Mehmeh River, Lokoja Nigeria are presented in Tables 1 to 4 .

Table 1: Physical analysis of Mehmeh river before the flood (Febuary 2012).

\begin{tabular}{lcccc}
\hline Parameters & \multicolumn{3}{c}{ Samples } & W.H.O. limit \\
\cline { 2 - 4 } & Barrack Otokiti & Phase II & Dunamis Bridge & $\mathbf{2 0 0 4}$ \\
\hline $\mathrm{pH}$ & 7.8 & 6.89 & 7.3 & $6.9-9.2$ \\
Temperature, ${ }^{0} \mathrm{C}$ & 28 & 29 & 26 & - \\
Turbidity, NTU & 3.7 & 4.3 & 4.9 & 2.5 \\
Conductivity, s/cm & 163 & 98 & 147 & 300 \\
Total solid, mg/L & 1053 & 1100 & 987 & $500-1500$ \\
\hline
\end{tabular}

Table 2: Chemical analysis of Mehmeh river before the flood.

\begin{tabular}{|c|c|c|c|c|c|c|}
\hline \multirow[t]{3}{*}{ Parameters } & \multicolumn{3}{|c|}{ Concentrations in $\mu \mathrm{g} / \mathrm{g}$} & \multirow{3}{*}{$\begin{array}{l}\text { Mean } \\
(\mu \mathrm{g} / \mathrm{g})\end{array}$} & \multirow[t]{3}{*}{ SD } & \multirow{3}{*}{$\begin{array}{c}\text { W.H.O. } \\
\text { Limit } 2004 \\
\quad(\mu \mathrm{g} / \mathrm{g})\end{array}$} \\
\hline & \multicolumn{3}{|c|}{ Samples } & & & \\
\hline & $\begin{array}{c}\text { Barrack } \\
\text { Otokiti }\end{array}$ & Phase II & $\begin{array}{c}\text { Dunamis } \\
\text { bridge }\end{array}$ & & & \\
\hline $\mathrm{Cd}$ & ND & ND & $\mathrm{ND}$ & - & - & 0.003 \\
\hline $\mathrm{Zn}$ & ND & ND & ND & - & - & 3.0 \\
\hline $\mathrm{Cu}$ & 0.03 & 0.02 & ND & 0.017 & 0.007 & 1.0 \\
\hline $\mathrm{Pb}$ & 0.02 & 0.02 & 0.01 & 0.017 & 0.006 & 0.01 \\
\hline $\mathrm{Fe}$ & 0.21 & 0.23 & 0.73 & 0.390 & 0.30 & 0.3 \\
\hline $\mathrm{Cr}$ & 0.07 & 0.01 & 0.03 & 0.037 & 0.030 & 0.05 \\
\hline $\mathrm{Ni}$ & 0.01 & 0.06 & 0.02 & 0.030 & 0.026 & 0.02 \\
\hline $\mathrm{Ca}$ & 0.78 & 0.81 & 1.26 & 0.950 & 0.270 & 75 \\
\hline $\mathrm{K}$ & 782 & 1059 & 987 & 942.67 & 143.72 & 20 \\
\hline $\mathrm{Na}$ & 2909 & 1021 & 2810 & 2246.67 & 1062.6 & 200 \\
\hline Alkalinity, mg/L & 126 & 105 & 118 & 116.33 & 10.60 & 200 \\
\hline
\end{tabular}


Table 3: Results of physical analysis of Mehmeh river during the flood.

\begin{tabular}{lcccc}
\hline Parameters & \multicolumn{3}{c}{ Samples } & W.H.O. limit \\
\cline { 2 - 4 } & Barrack Otokiti & Phase II & Dunamis Bridge & 2004 \\
\hline $\mathrm{pH}$ & 6.9 & 6.5 & 6.3 & $6.9-9.2$ \\
Temperature, ${ }^{0} \mathrm{C}$ & 28 & 29 & 29 & - \\
Turbidity, NTU & 7.8 & 7.5 & 8.0 & 2.5 \\
Conductivity, s/cm & 176 & 183 & 180 & 300 \\
Total solid, $\mathrm{mg} / \mathrm{L}$ & 1453 & 1400 & 1450 & $500-1500$ \\
\hline
\end{tabular}

Table 4: Chemical analysis of Mehmeh river during the flood.

\begin{tabular}{lcccccc}
\hline Parameters & \multicolumn{3}{c}{ Concentrations in $\boldsymbol{\mu g} / \mathbf{g}$} & \multirow{3}{*}{$\begin{array}{c}\text { Mean } \\
(\boldsymbol{\mu g} / \mathbf{g})\end{array}$} & SD & $\begin{array}{c}\text { W.H.O. Limit } \\
\mathbf{2 0 0 4}(\boldsymbol{\mu g} / \mathbf{g})\end{array}$ \\
\cline { 2 - 4 } & $\begin{array}{c}\text { Barrack } \\
\text { Otokiti }\end{array}$ & $\begin{array}{c}\text { Phase } \\
\text { II }\end{array}$ & $\begin{array}{c}\text { Dunamis } \\
\text { bridge }\end{array}$ & & & \\
\hline $\mathrm{Cd}$ & $\mathrm{ND}$ & $\mathrm{ND}$ & $\mathrm{ND}$ & - & - & 0.003 \\
$\mathrm{Zn}$ & $\mathrm{ND}$ & $\mathrm{ND}$ & $\mathrm{ND}$ & - & - & 3.0 \\
$\mathrm{Cu}$ & 0.07 & 0.06 & 0.01 & 0.047 & 0.032 & 1.0 \\
$\mathrm{~Pb}$ & 0.90 & 0.30 & 0.70 & 0.63 & 0.31 & 0.01 \\
$\mathrm{Fe}$ & 0.48 & 0.89 & 1.05 & 0.81 & 0.29 & 0.3 \\
$\mathrm{Cr}$ & 0.69 & 0.24 & 0.62 & 0.52 & 0.24 & 0.05 \\
$\mathrm{Ni}$ & 0.16 & 0.63 & 0.25 & 0.35 & 0.25 & 0.02 \\
$\mathrm{Ca}$ & 1.10 & 2.70 & 3.70 & 2.50 & 1.31 & 75 \\
$\mathrm{~K}$ & 1500 & 1575 & 1550 & 1541.67 & 38.19 & 20 \\
$\mathrm{Na}$ & 4500 & 2575 & 4600 & 3891.67 & 1141.36 & 200 \\
$\mathrm{Alkalinity}, \mathrm{mg} / \mathrm{L}$ & 98 & 86 & 90 & 91.33 & 6.11 & 200 \\
\hline
\end{tabular}

\section{DISCUSSION}

pH

The $\mathrm{pH}$ ranges from 6.89 to 7.8 in the water before the flood, and $6.3-6.9$ during the flood. The $\mathrm{pH}$ values are higher before the flood than during the flood and this variation may be due to the exposure of the river water to atmosphere, biological activities and temperature control (Adebowale et al., 2008).

\section{Temperature}

The observed temperature before the flood ranged from $26-29{ }^{\circ} \mathrm{C}$, while the recorded temperature during the flood was 28 - $29{ }^{0} \mathrm{C}$. Due to weather conditions and massive movement of water bodies, the flood temperature recorded a slightly higher value than the temperature during the flood (Bahadur and Chandra, 1996).

\section{Turbidity}

The turbidity values ranged from $3.7-$ 4.9 NTU before the flood and 7.5 - 8.0 NTU during the flood. The W.H.O. limit turbidity is 2.5NTU (W.H.O, 2004). Therefore, the probability of presence of pathogenic organisms is high in the water samples (Gupta et al., 2003).

\section{Conductivity}

The observed electrical conductivity for the three sampling points before the flood are 163,98 and $147 \mathrm{~s} / \mathrm{cm}$ respectively for Barrack Otokiti, Phase II and Dunamis bridge. 
The recorded conductivity during the flood are 176, 183 and $180 \mathrm{~s} / \mathrm{cm}$ for Barrack Otokiti, Phase II and Dunamis bridge respectively. This result suggests a sharp increase in comparison to the values obtained before the flood. The increase indicates a larger quantity of dissolved mineral salts (Trivedy and Goyal, 1986). The conductivity of water is a measure of capacity of a solution to conduct electrical current through it and depends on the concentration of ion and load of nutrients. As most of the salts in water are present in ionic forms, they make water capable of conducting current. The conductivity, thus serves as a good and rapid measure of the total dissolved solids in water (Zaimoglu et al., 2006).

\section{Total solid}

The total solid recorded before the flood ranged from $989-1100 \mathrm{mg} / \mathrm{L}$ and 1400 $-1453 \mathrm{mg} / \mathrm{L}$ during the flood. The suspended solids determination is particularly useful in the analysis of sewage and other waste waters and is significant as BOD determination. It is used to evaluate the strength of domestic wastewaters and efficiency of treatment units. Suspended solids are objectionable in river for many reasons. Putrefaction may set in and the dissolved oxygen may be depleted. Previous studies have reported high suspended solids during rainy season (Abbasi et al., 2002). The high suspended solid presence in the water before the flood could be attributed to the dumping of refuse and sewage on the water body by communities living along the water trajectory. The increment during the flood could be ascribed to the inflow of particulate and organic matter as the water quantity increases.

\section{Alkalinity}

The alkalinity ranged from $105-126$ $\mathrm{mg} / \mathrm{L}$ (before the flood) and $86-98 \mathrm{mg} / \mathrm{L}$ during the flood. These high amounts of alkalinity before and during the flood could be due to discharge of wastewater from industrial and domestic sources into the Mehmeh River.
Before the flood, samples around the Barrack Otokiti recorded higher alkalinity value than other sampling points. This may be ascribed to the population density around the area and the subsequent effect of waste discharge into the river body. The results obtained during the flood differed from that before the flood due to the high amount of particles and microorganisms that are present in the water body which is capable of reducing the alkalinity. Increase in dilution may be responsible for relative lower values in rainy season.

\section{Metals}

The presence of metals in the river was equally recorded for most studied. Cadmium and $\mathrm{Zn}$ were not observed at any concentration before and during the flood. However, $\mathrm{Cu}$ was observed at Phase II and Barrack Otokiti with respective concentrations of $0.02 \mu \mathrm{g} / \mathrm{g}$ and $0.03 \mu \mathrm{g} / \mathrm{g}$. Copper was not detected at Dunamis Bridge. This may primarily be the result of dilution as the water flows from Barrack Otokiti to Dunamis Bridge. In contrast to this, $\mathrm{Cu}$ recorded elevated concentrations during the flood which can be attributed to the influx of particulate matter along the water path as it flows. The $\mathrm{Cu}$ range recorded during the flood is $0.01-0.07 \pm 0.032 \mu \mathrm{g} / \mathrm{g}$.

Lead was observed at a range of $0.01-$ $0.02 \pm 0.01 \mu \mathrm{g} / \mathrm{g}$ before the flood and $0.30-$ $0.90 \pm 0.31 \mu \mathrm{g} / \mathrm{g}$ during the flood. This distribution along the water course may be ascribed to the effect of refuse dump and wastewater discharged into the body. The concentrations increased during the rainy season as a result of the increase in particulate matter content and flooding. Iron before the flood was recorded at a range of $0.21-0.73 \pm$ $0.30 \mu \mathrm{g} / \mathrm{g}$ and $0.48-1.05 \pm 0.29 \mu \mathrm{g} / \mathrm{g}$ during the flood. Chromium concentration before the flood was recorded with a range of $0.01-0.07$ $\pm 0.03 \mu \mathrm{g} / \mathrm{g}$ and $0.24-0.69 \pm 0.24 \mu \mathrm{g} / \mathrm{g}$ during the flood. Observed concentrations of $\mathrm{Ni}$ before and during the flood are 0.01-0.06 $\pm 0.03 \mu \mathrm{g} / \mathrm{g}$ and $0.16-0.63 \pm 0.25 \mu \mathrm{g} / \mathrm{g}$ 
respectively, while that of $\mathrm{Ca}$ is $0.78-1.26 \pm$ $0.27 \mu \mathrm{g} / \mathrm{g}$ before the flood and $1.10-3.70 \pm$ $1.31 \mu \mathrm{g} / \mathrm{g}$ during the flood.

The analysis of the river sample for $\mathrm{K}$ indicated concentrations in the range 782 $1059 \pm 143.72 \mu \mathrm{g} / \mathrm{g}$ before the flood and 1500 - $1575 \pm 38.19 \mu \mathrm{g} / \mathrm{g}$ during the flood. Observed concentration for $\mathrm{Na}$ is $1021-2909$ $\pm 1062.60 \mu \mathrm{g} / \mathrm{g}$ before the flood and 2575 $4600 \pm 1141.36 \mu \mathrm{g} / \mathrm{g}$ during the flood.

The increase in the concentration of all the measured species can be attributed to the increase in the particulate matter as a result of flooding. Expectedly, the mean values of these metals (except $\mathrm{Cd}, \mathrm{Zn}, \mathrm{Cu}, \mathrm{Cr}$ and $\mathrm{Ca}$ ) exceed the W.H.O. standard and are therefore not fit for domestic and industrial consumption.

\section{Conclusion}

From the results and discussions, it can be observed that there was an increase in the physicochemical parameters studied during the periods of flooding compared to periods before the flood. This was attributed to the increase in the particulate matter along the water course. Being a river that runs through a densely populated area, anthropogenic factors such as wastewater and effluent discharge (both from domestic and industrial sources) may have contributed to the objectionable concentrations observed. These objectionable concentrations may have a far reaching impact on the inhabitants and the river due to the fact that some households use the river water for domestic consumption.

\section{REFERENCES}

Abbasi SA, Khan FI, Sentilvelan K, Shabudeen A. 2002. Modeling of Backingham canal water quality. Indian J. Environ. Hlth., 44(4): 290-297.
Adebowale KO, Agunbiade FO, Olu-Owolabi BI. 2008. Impacts of natural and anthropogenic multiple sources of pollution on the environmental conditions of Ondo State Coastal water, Nigeria. EJEAFChe, 4: 2797-2811.

Bahadur Y, Chandra R. 1996. Monitoring the quality of River Ramgana waters at Bareilly. Poll. Res., 15(1): 31-33.

Burrell DC. 1975. Atomic Absorption Spectroscopic Analysis of Heavy Metal Pollutants in Water. Ann Arbor Science Publishers, Inc, Ann Arbor, Mich.

Gupta S, Bhatnagar M, Jain R. 2003. Physicochemical characteristics and analysis of $\mathrm{Fe}$ and $\mathrm{Zn}$ in tubewell water and sewage water of Bikaner City. Asian J. Chem., 15: 727.

Subba Rao C, Subba Rao NV. 1995. Ground water quality in residential colony. Ind. J. Environ. Hlth., 37(4): 295-300.

SMEWW. 2000. Standard Methods for the Examination of Water and Wastewater, APHA, AWWA, and WEF $21^{\text {st }}$ Edition.

SMEWW. 2005. Standard Methods for the Examination of Water and Wastewater, APHA, AWWA, and WEF $21^{\text {st }}$ Edition.

Toufeek MEF. 2005. Distribution of some heavy metals in lake Nasser water, Egypt. J. Aquat. Biol and Fish, 9: 131149.

Trivedy RK, Goyal PK. 1986. Chemical and biological methods for water pollution studies. Enviro-Media Karad; 3-96.

WHO. 2004. World Health Organisation Guidelines for Drinking Water Quality. WHO: Geneva.

Zaimoglu Z, Yavuz S, Davutoglu IO, Hazir I, Yuceer A. 2006. Pollutant monitoring of a drainage canal receiving industrial and agricultural waste water Incukurova plain. J. Biol. Sci., 6(4): 646-650. 